\title{
PSYCHOLOGY
}

\section{Features of Demonstration of Hardiness' Components of Personality}

\author{
O. Chykhantsova
}

Kostiuk Institute of Psychology of National Academy of Educational Sciences of Ukraine, Kyiv, Ukraine

Corresponding auther. E-mail: chyhantsova@gmail.com

Paper received 25.01.18; Revised 29.01.18; Accepted for publication 30.01.18.

\begin{abstract}
https://doi.org/10.31174/SEND-PP2018-155VI65-13
\end{abstract}
Abstract. The article deals with the phenomenon of individual hardiness and its value-semantic. It is determined that hardiness can be a factor of optimal self-realization and psychological quality of individual life and a main personal variable that mediates the influence of stress factors on the somatic health and on the activity success. The results of empirical studies of hardiness components which form and develop as a valuable individual formation are presented. The obtained results allowed to establish that individual hardiness is caused by a set of interacting parameters. Based on the results of our study, we can conclude that individual with hardy personality have more positive life perspective.

Keywords: individual hardiness, components, values, personality.

Topicality. The problem of difficult life situations is developed by many authors who relies on such concepts as strategies for overcoming difficult life situations and post-traumatic stress disorder.

Also, hardiness is considered as a man's personality inventory, as a link between stressful life situations and illness and adaptation to conditions. According to this approach hardiness is a psychological analogue of person's vital lifeline which reflects the extent of overcoming and adapting by him to the given circumstances, of himself, as well as the extent efforts on self-improvement and on the circumstances of his life.

Considering hardiness as a complex integral property of individual, we introduced it as a multilevel, holistic entity that includes levels which correspond to the hierarchical structure of individual qualities. Hardiness is an integral system of relationships with the world, it is the necessary resource which can contribute to increase physical and mental man health that is associated with selfrealization, self-affirmation and transcendence of individual.

So, a concept 'hardiness' was introduced by S. Kobasa and S. Maddi and is on the intersection of theoretical views of existential psychology and applied area of stress psychology and co-ownership with it. Analyzing work of American psychologists S. Kobasa and S. Maddi who first introduced a concept of hardiness we can state that this phenomenon consists of three components: commitment, control and challenge [7-12].

If you are strong in the $\mathrm{C}$ of challenge, you accept that life is by its nature stressful, and see those stressful changes as an opportunity to grow in wisdom and capability by what you learn through trying to turn them to your advantage. In this, you think that you can learn from failures as well as successes. You do not think you are entitled to easy comfort and security. Instead, you feel that fulfillment can only be gained by having turned the stresses into growth opportunities. Another $\mathrm{C}$ of hardy attitudes is commitment, which involves the belief that no matter how bad things get, it is important to stay involved with whatever is happening, rather than sink into detachment and alienation. And the third $\mathrm{C}$ of hardiness is control, which leads you to believe that no matter how bad things get, you need to keep trying to turn the stresses from potential disasters into growth opportunities. It seems like a waste of time to let yourself sink into power- lessness and passivity. To truly express existential courage, a person must possess all 3Cs of commitment, control, and challenge [10;12].

Formulation of the problem. Existential psychology is the prerequisite for concept formulating 'hardiness'. In the opinion of existential psychologists and philosophers, all events in our lives are the result of decision-making, regardless of whether they are significant or insignificant, conscious or unconscious. So, expressing by existential terminology hardiness is an existential courage. Actually, hardiness arose as a model of relations and strategies which together contribute to the transformation of stressful circumstances from potential catastrophes to the possibility of personal growth $[2 ; 3 ; 4 ; 10]$.

Such as, a concept of S. Maddi's hardiness includes psychological (increasing of interest to the environment, changing attitudes towards others, etc.) and activity (mastering of stressful situations, goal achieving, health caring) components, so we consider to examine this phenomenon more widely.

As a result structure of individual hardiness, in our opinion, should be expanded with such personal parameters as: goals in life, self-efficiency; self-attitude, autonomy and well-being.

While hardiness is a holistic system formation that combines meaningful goals and values for the individual, self-adaptation, stylistic characteristics of behavior, determined by attitudes and beliefs about the world, social environment and its place in it. Moreover, the development of such hardiness components as commitment, control and challenge, contribute to the formation of a positive attitude towards to oneself and life events.

Goal of research is to explore hardiness aspects of individual empirically which form and develop as a holistic personal entity.

Research methods. To achieve this goal and to solve the problems of our research the following research methods were used: S. Muddi's hardiness test (D. Leontiev's and O. Rasskazova adaptation); S. Pantyleev's, V. Stolin's test-questionnaire of personal self-conception; J. Krambo's, L. Maholik's Purpose-in-Life Test (PIL) (D. Leontiev's adaptation); E. Osin's self-determination test (K. Sheldon's modification self-determination scale); K. Riff's scale of psychological well-being (T. Shevelenkova's and T. Fesenko's adaptation).

The main sample of our research consists of 110 peo- 
ple who are engaged in various professional activities and different in age.

Results of our research. Based on the results of our research we adhere to the view that hardiness manifests as a characteristic of man attitude to himself, surrounding world and nature of interaction with it which gives strength and motivate it to self-realization, leadership, a healthy way of thinking and behavior; makes it possible to feel oneself significant and valuable enough to engage fully in solving life problems without paying attention to the presence of stressful factors and changes. The first component of hardiness is 'commitment'. Commitment is belief of an individual in respect of the importance of the activities. In fact, it is the sample of those who desire to have a deep sense of engaging their lives activities [5].

The second component of hardiness is 'control'. Control of circumstances organizes the search of influence ways on the results of stressful changes, as opposed to falling into a state of helplessness and passivity. The third component of hardiness - 'challenge' helps a person to be open to the surrounding world, other people, society. Its essence lies in the perception of personality of life events and problems as a challenge and examination personally for oneself. These three components form a general hardiness.

According to the mentioned it was analyzed the correlation relations between described above components of structure of personal qualities that is indicators of general hardiness and life-purpose orientations, self-conception, self-actualization and psychological well-being.

Let's consider the significant correlation coefficients between general hardiness and other components (Table $1)$.

Table 1. Features of personality parameters of hardiness

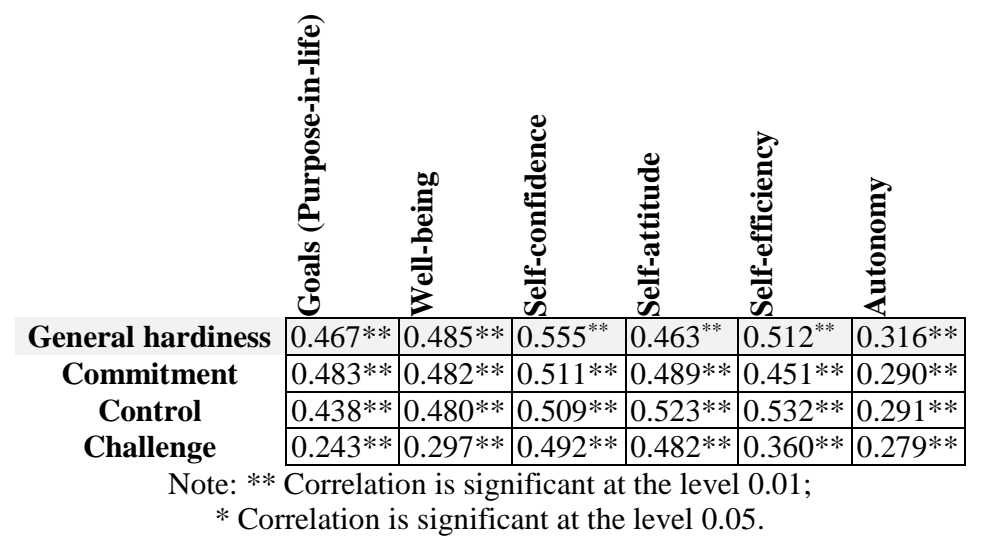

First of all we consider the significant correlation coefficients between the indicators of general hardiness and self-confidence $(r=0.555 ; \mathrm{p}<0.01)$ and self-attitude $(\mathrm{r}=$ $0.463 ; \mathrm{p}<0.01)$. It means that self-confidence and selfattitude perform like the most important factor in personal self-determination. A person who shares the selfconfidence and self-attitude of personality is characterized by success in overcoming of adverse difficulties of life.

Thus, a person who chooses his own activity, his own way, can influence the outcome of what is happening, treats himself as a confident, independent, strong-willed person, worthy of respect. And in contrast, if a person is convinced that he can not influence the outcome of what is happening, feels helpless, then he gets a feeling of dissatisfaction with his capabilities, doubts about the ability to cause respect.

Links of hardiness with self-attitude and selfconfidence are observed with all scales and at different levels of significance. These links are mediated by social factors and professional orientation.

Hardiness reveals links with purpose in life as the highest level of self-realization of the individual. The connection of hardiness with all the scales of Purpose-inLife Test (PIL) is traced. All connections are positive. This means that to be viable it is necessary to have a goal in life, to perceive the very process of life as interesting, emotionally rich and filled with meaning, to have the conviction that a person is given control over his life, freely make decisions and implement them. And, conversely, a person who has reached the highest level of self-realization, with the established system of meaningful orientations, will have a high hardiness.

Corresponding to the results of correlation coefficient a direct significant relationship between hardiness with autonomy was found $(\mathrm{r}=0.316 ; \mathrm{p}<0.01)$. It can be explained by the fact that the aspiration for autonomy is the result of willingness to conquer their interests to the public. Man wants to feel himself as part of the collective and wants to conquer his interests to the interests of society, wants to be a part of society instead of independent, both in thoughts and in actions. The desire to be dependent and not be responsible for any actions explain the low scores on the challenge scale $(r=0.279 ; \mathrm{p}<0.01)$.

The results of the research by the Riff's scale of psychological well-being $(r=0.485$; $\mathrm{p}<0.01)$ presented that respondents know their advantages and disadvantages and hold the opinion that their life makes sense. Respondents have a high level of psychological well-being, which can be due to overall satisfaction with their own lives.

Self-efficiency or confidence in its ability to perform certain activities [2], often correlated with the component of control of viability. Most respondents have a persistent belief that their efforts and perseverance can have a significant impact on the outcome of the activity while the outcome of the situation is far from always always determined and clear. At high control values $(r=0.512 ; \mathrm{p}$ $<0.01)$ ), people feel power over circumstances.

The resalts of our research in Table 1 present that the highest control indicators with all structural components of individual hardiness are revealed. This is due to the fact that control is the belief that the struggle allows to influence on the result of what is happening even if this 
influence is not absolute and success is not guaranteed; motivates to find ways to influence the results of stressful changes as opposed of falling into a state of helplessness and passivity. This desire for a result by controlling its actions and manifestations in interaction with the world.

Figure 1 demonstrate that the hardy persuasion influences the assessment of the situation through a willingness to act actively and confidence in the ability to influence the situation.

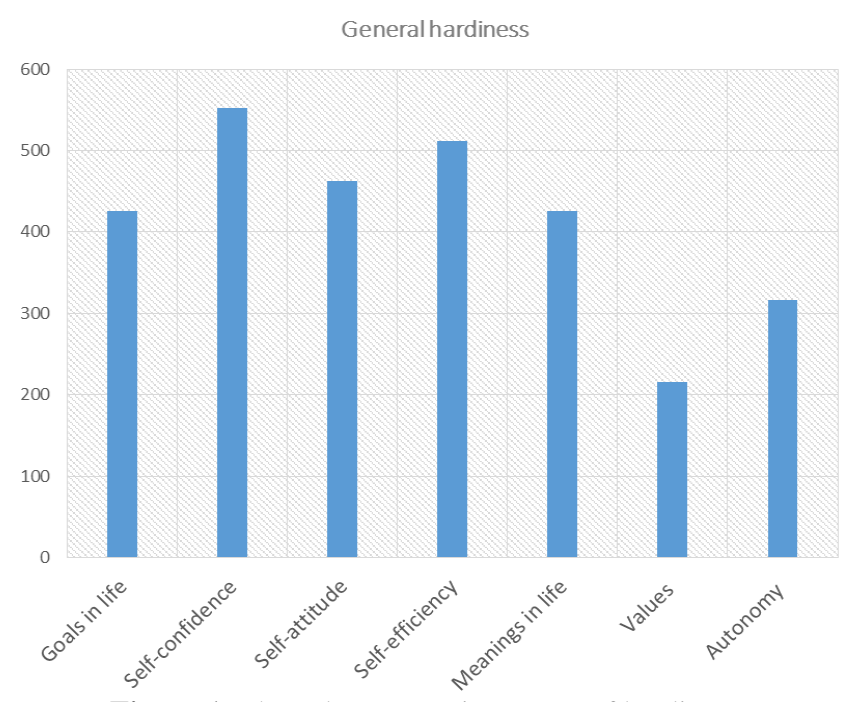

Figure 1. The value-semantic aspects of hardiness

This situation is perceived as less traumatic. Also, vitality contributes to an active overcoming of difficulties. It stimulates the care of one's own health and well-being, due to which stress and stress experienced by a person do not develop into chronic and do not lead to psychosomatic diseases.

Also, we believe that hardiness can be learned. It is best, needless to say, if that learning takes place early in your life, through the nature of your interactions with your parents and other mentors $[6 ; 12]$. But, hardiness can be learned at any time in life through our hardiness training program $[6 ; 10 ; 12]$.

In this way, hardiness can be considered as an analogue of human life strength which reflects a measure of overcoming by himself certain life circumstances, oneself, as well as the amount of efforts, working on himself and on the circumstances of his life.

In such a way, hardiness allows to achieve a certain optimum in determining life prospects, allows to maintain a balance between the needs of individual and its pretensions and aspirations.

Summary. In the course of the study, we have solved all the tasks in order to study the individual hardiness and the relationship with other factors that mediate it.

The results of correlation analysis showed a significant positive correlation relationships (on $\mathrm{p}<0.01$ ) between all indicators of hardiness components and this in its turn indicates that life-sustaining beliefs extend the prospect of personal interaction with the world, extend the time perspective, make it possible to correlate the past, the future and the present, to analyze own live that increases the possibility of gaining a new life experience.

In conclusion, hardiness can be considered as an analogue of human life strength which reflects a measure of overcoming by himself certain life circumstances, oneself, as well as the amount of efforts, working on himself and on the circumstances of his life.

So, hardiness allows to achieve a certain optimum in determining life prospects, allows to maintain a balance between the needs of individual and its pretensions and aspirations.

The results of research can be applied in the practice of psychologist, psychological service, as well as in the development of training programs, in particular hardiness programs.

\section{REFERENCES}

1. Bandura, A. Self-Efficacy: Toward a Unifying Theory of Behavior Change // Psychological Review, 1977. Vol. 84, P. 191-215.

2. Baranauskienè, I., Serdiuk, L., Chykhantsova, O. Psychological characteristics of school-leavers' hardiness at their professional self-determination. Social Welfare: Interdisciplinary Approach, 2016. Vol 2, No 7, P. 64-73.

3. Besharat, M.A. Relationship between hardiness and interpersonal problems / M.A. Besharat // Journal of Psychological studies, 2009. - № 5(4) - C. 25-32.

4. Firestone, L., Firestone, R., Catlett, J. Creating a life of meaning and compassion: The wisdom of psychotherapy // Washington, DC: American Psychological Association, 2003.

5. Haghighatgoo, M. The relationship between hardiness and time perspective in students // Procedia - Social and Behavioral Sciences, 2011. Is. 30. P. 925-928.

6. Khoshaba, D.M., Maddi, S.R. Early Antecedents of Hardiness // Consulting Psychology Journal, 1999. - Vol. 51, N 2, P.
106-117.

7. Khoshaba, D.M., Maddi, S.R. Hardi Training: managing stressful change (5th ed.). Irvine: Hardiness Institute, 2004.

8. Kobasa, S.C., Maddi, S.R., Kahn, S. Hardiness and health: A prospective study of Personality and Social Psychology // Journal of personality and social psychology, 1982. 42, 168177.

9. Maddi, S.R. Hardiness: An Operationalization of Existential Courage // Journal of Humanistic Psychology, 2004. Vol. 44, No. 3, P. 279-298.

10. Maddi, S.R., Khoshaba, D. Hardiness and Mental Health // Journal of Personality Assessment, 1994. Vol. 63, № 2, P. 265-274.

11. Maddi, S.R. Hardiness: The courage to grow from stresses // The Journal of Positive Psychology, 2006. 1(3). P. 160-168.

12. Maddi, S.R. The story of hardiness: twenty years of theorizing, research, and practice // Consultation Psychology. 2002, Vol. 54, P. 173-185.

\section{Особенности проявления компонентов жизнестойкости личности}

\section{Е. Чиханцова}

Аннотация. В статье рассматривается феномен жизнестойкости и его ценностно-смысловые аспекты. Установлено, что жизнестойкость может быть фактором оптимальной самореализации и психологического качества жизни личности и главной личной переменной, которая опосредует влияние стрессовых факторов на соматическое здоровье и на успех деятельности. Приводятся результаты эмпирических исследований компонентов жизнестойкости, которые формируются и развиваются как ценное индивидуальное образование. Полученные результаты позволили установить, что индивидуальная жизнестойкость вызвана набором взаимодействующих параметров. Основываясь на результатах нашего исследования, мы можем заключить, что у человека с высоким уровнем жизнестойкостью есть более позитивная перспектива жизни.

Ключевые слова: индивидуальная жизнестойкость, компоненты, иенности, личность. 